\title{
PENERAPAN METODE MISSOURI MATHEMATICS PROJECT (MMP) UNTUK PENGUASAAN PERSAMAAN DAN PERTIDAKSAMAAN KUADRAT SATU VARIABEL
}

\section{APPLYING MISSOURI MATHEMATICS PROJECT (MMP) METHODE TO MASTERY THE QUADRATIC EQUATIONAND INAQUALITY OF ONE VARIABLE}

\author{
ETTY SOELISTYOWATI WULANDARI \\ SMK Negeri 52 Jakarta
}

\begin{abstract}
Received: March 09,2021 The ability to master the material quadratic equations and inequatnies one variable in Revised: September 30,2021 mathematics learning in SMK is a pivotal important, This notion is based on a foundation in Accepted: November 26, 2021 learning mathematics with a higher level and according to KKM. The problem in this study is whether the application of the Missouri Mathematical Project (MMP) learning model can improve students' mastery in mathematics. The number of participant in this study was 32. The sample was taken by random sampling method. Data collection uses written test of mathematics mastery and non-test, that was, observation and questionnaires. The data analysis procedure uses simple statistics with the help of an excel application. The study has come up with the following results in the first cycle the average score was 73 in the second cycle to an average score of 79. From the results of the study, it can be concluded that overall the MMP learning method can enhance students' mastery.
\end{abstract}

\begin{abstract}
Abstrak
Kemampuan penguasaan materi persamaan dan pertidaksamaan kuadrat satu variabel dalam pembelajaran matematika di SMK merupakan suatu hal yang sangat penting, karena merupakan pondasi dalam pembelajaran matematika yang levelnya lebih tfnggi dan berpengaruh terhadap hasil belajar atau ketuntasan belajar yang telah ditentukan kriteria ketuntasan minimalnya (KKM). Permasalahan dalam penelitian ini adalah apakah penerapan model pembe/ajaran Missouri Mathematic Project (MMP) dapat meningkatkan penguasaan peserta didik pada pe/ ajaran matematika materi persamaan dan pertidaksamaan kuadrat satu variabel. Sedangkan tujuan dari penelitian ini adalah untuk meningkatkan penguasaan peserta didik pada pelajaran matematika materi persamaan dan pertidaksamaan kuadrat satu variable. Model pembelajaran MMP ini mempunyai lima tahapan yaitu: review, pengembangan, latihan terkontrol, latihan mandiri (seatwork), dan tahap penugasan (PR). Penelitian ini menggunakan Penelitian Tindakan Kelas dilakukan dengan dua siklus yang terdiri dari empat tahap, yaitu: 1. Persiapan, 2. Pelaksanaan Tindakan, 3. Pengamatan, 4. Refleksi. Partisipan penelitian ini berjumlah 32 peserta didik Pengambilan sampel dalam penelitian ini dengan metode random sampling. Pengumpulan data menggunakan tes tulis penguasaan matematika dan nontes dengan observasi dan angket. Prosedur analisis data menggunakan statistika sederhana dengan bantuan aplikasi excel yang diikuti dengan intreprestasi dan pemaknaan terhadap hasil yang dicapai peserta didik. Hasil penelitian menunjukkan bahwa pada siklus 1 rata-rata nilai 73 sementara pada siklus II mengalami peningkatan penguasaan menjadi rata-rata nilai 79. Kesimpulanyang dapat dihasilkan dari penelitian ini bahwa melalui metode pembelajaran MMP dapat meningkatkan penguasaan peserta didik dan dapat dikembangkan sebagai alternatif metode pembelajaran yang dapat digunakan dalam pembelajaran matematika.

Keywords: Missouri mathematics Project (MMP), mastery, One-variable quadratic equations and

Missouri mathematics Project (MMP), Penguasaan, Persamaan dan pertidaksamaan kuadrat satu variabel
\end{abstract} Kata kunci: inequalities

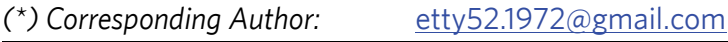

How to Cite: Wulandari, E.S., (2021). Penerapan Metode Missouri Mathematics Project (MMP) Untuk Penguasaan Persamaan Dan Pertidaksamaan Kuadrat Satu Variabel. Jurnal Lingkar Mutu Pendidikan, 18 (2), 160-166. https://doi.org/10.54124/ilmp.v18i1.27

\section{PENDAHULUAN}

Pengembangan kemampuan matematika dimulai dari level yang paling rendah hingga menuju yang paling tinggi. Penguasaan materi persamaan dan pertidaksamaan kuadrat satu variabel merupakan satu 
diantara level penguasaan yang harus dimiliki oleh peserta didik terutama peserta didik SMK. Terdapat banyak penelitian yang dilakukan terkait dengan materi persamaan dan pertidaksamaan kuadrat satu variabel metode pembelajaran Missouri Mathematics Project (MMP) diantaranya penelitian yang dilakukan oleh (Sri Adi.Widodo, 2011) "Efektifitas Model Pembelajaran Team Accelerated Instruction pada peserta didik kelas X SMK TUNAS HARAPAN," hasil penelitiannya menyimpulkan penggunaan model kooperatif tipe TAI belum efektif digunakan untuk mata pelajaran matematika pokok bahasan pertidaksamaan kuadrat dan persamaan." (Sugiarto, 2009) "Keefektifan Implementasi Model pembelajaran MMP materi pokok pertidaksamaan kuadrat persamaan dan pada peserta didik kelas X SMAN 1 Ungaran", hasilnya disimpulkan bahwa model MMP lebih baik daripada pembelajaran ekspositori untuk mata pelajaran pertidaksamaan kuadrat dan persamaan (Sartina, 2018) menggabungkan antara dua model MMP dengan model pembelajaran Explicit Intruction (EI) untuk mengetahui bagaimana penguasaan matematika peserta didik. Hasil penelitiannya implementasi model pembelajaran Explicit Missouri Mathematics Instruction (EMMI) dapat meningkatkan pemahaman konsep peserta didik. Dalam penelitian yang dilakukan (Rahmawati, 2017)"

Model Pembelajaran MMP dengan pembelajaran Number Heads Together (NHT) terhadap kemampuan pemecahan masalah matematis ditinjau dari kemandirian belajar peserta didik kelas VII SMP Negeri 9 Bandar Lampung" model pembelajaran MMP lebih baik daripada model Number Heads Together (NHT) dan konvensional karena peserta didik dapat aktif dan mengembangkan kemampuan pemecahan masalah matematis dalam penelitian pembelajaran matematika.

Dengan melihat penelitian-penelitian yang dilakukan diatas banyak metode, pendekatan dan strategi yang berpeluang untuk digunakan dalam pembelajaran dan pengajaran matematika, bahwa untuk melihat keefektifan, penguasaan dan kemandirian peserta didik dalam pembelajaran matematika menggunakan metode M M P karena model pembelajaran MMP mengandung tahapan: pengulasan kembali,pengembangan, kerja bersama (latihan terkontrol), kerja sendiri dan penutup (membuat resume pelajaran, membuat perenungan tentang hal-hal baik yang sudah dilaksanakan serta hal-hal kurang baik yang harus dihilangkan). Pendidik dan peserta didik melihat ulang materi yang telah dipelajari pada pembelajaran sebelumnya hal itu dilakukan tahap pengulasan kembali. Kegiatan ini membantu peserta didik untuk mem pertaja m ingatan materi yang telah dipelajari,dengan pertanyaan-pertanyaan pancingan dari pendidik ketika peserta didik belum mengingat sepenuhnya materi pelajaran yang dimaksud. Selanjutnya pendidik menyampaikan perluasan materi dari materi yang telah disampaikan digali dengan pertanyaan-pertanyaan pancingan dari pendidik untuk mengetahui pembelajaran sebelumnya juga

Hal tersebut dalam rangka pengembangan. Tahapan ini dikombinasikan dengan teman sekelas berkoordinator untuk dibentuk kelompok kecil dengan teman-teman sekelas dengan kerja kooperatif. Satu paket soal sambil diawasi oleh pendidik agar tidak terjadi miskonsepsi direspon oleh peserta didik .Peserta didik diminta untuk mengerjakan soal-soal secara mandiri setelah melakukan kerja secara berkelompok, Tujuannya untuk mengetahui tingkat kemampuan penguasaan peserta didik pada tiap-tiap individu. Kemampuan peserta didik dikuatkan dengan pemberian tugas-tugas yang berhubungan dengan materi yang baru saja mereka pelajari yang dilakukan pada tahap akhir.

Berdasarkan keragaman hasil seperti tampak pada uraian diatas maka peneliti menggunakan metode MMP untuk mengetahui apakah penguasaan materi persamaan dan pertidaksamaan kuadrat satu variable peserta didik SMK Negeri 52 Jakarta meningkat. Adapun tujuan yang ingin dicapai dalam penelitian ini adalah: untuk mengetahui apakah metode pembelajaran MMPdapat meningkatkan pengusaan peserta didik pada mata pelajaran matematika materi persamaan dan pertidaksamaan Kuadrat satu variabel peserta didik kelas XI semester ganjil di SMK Negeri 52 Jakarta Tahun pelajaran 2019/2020.

Peserta didik yang menggunakan model pembelajaran MMP lebih baik dibandingkan prestasi belajar matematika peserta didik yang menggunakan model pembelajaran Mekanistik, hal ini didukung dari hasil penelitian yang ditunjukkan (Suwito, 2013).

Simpulannya bahwa model pembelajaran M M P menghasilkan has il belajar matematika yang lebih baik daripada model pembelajaran langsung, baik secara umum maupun dilihat dari tiap-tiap tingkat kemampuan spasial. Peserta didik yang memiliki kemampuan spasial tinggi menghasilkan prestasi belajar matematika yang lebih baik daripada peserta didik yang memiliki kemampuan 
spasial sedang dan rendah sedangkan peserta didik yang memiliki kemampuan spasial sedang menghasilkan prestasi belajar matematika yang sama baiknya dengan peserta didik yang mempunyai kemampuan spasial rendah hal ini sesuai dengan penelitian (Faradhila, 2013).

\section{METODE PENELITIAN}

Penelitian ini dilakukan selama 4 bulan mulai Agustus 2019 sampai November 2019 pada semester ganjil tahun pelajaran 2019/2020. Penelitian Tindakan Kelas (PTK) ini mengacu pada kalender akademik satuan pendidikan dalam menentukan waktu penelitian karena memerlukan beberapa siklus yang membutuhkan proses belajar mengajar yang efektif di kelas.

Penelitian Tindakan Kelas dilaksanakan di SMK Negeri 52 Jl. Taruna Jaya, RT. 02/ RW. 14 kelurahan Cibubur Kecamatan Ciracas Kabupaten Jakarta Timur. Kode Pos 13720, Telp/ Fax. (021) 8732519, web site: www.smkn52-jkt.sch.id pada tahun 2019/2020 semester ganjil pada kelas XI Desain Interior dan Teknik Furnitur (DITF) B. Subjek Penelitian Tindakan kelas adalah peserta didik kelas XI Desain Interior dan Teknik Furnitur (DITF) B tahun pelajaran 2019/2020 semester ganjil SMK Negeri 52 Jakarta berjumlah 32 peserta didik dengan perincian jumlah perempuan 13 orang dan peserta didik laki-laki 19 orang.

Penelitian ini adalah penelitian tindakan kelas atau disebut juga Classroom Action Research (CAR). Desain penelitian yang dipergunakan berbentuk siklus model Kemmis dan McTaggrat yang terdiri dari duasiklus, setiap siklus terdiri dari empat tahap, yaitu perencanaan, pelaksanaan tindakan, pengamatan dan refleksi. Penelitian akan dilanjutkan pada siklus berikutnya jika tindakan yang diberikan belum mencapai indikator yang diharapkan. Alur penelitian dapat digambarkan sebagai berikut.

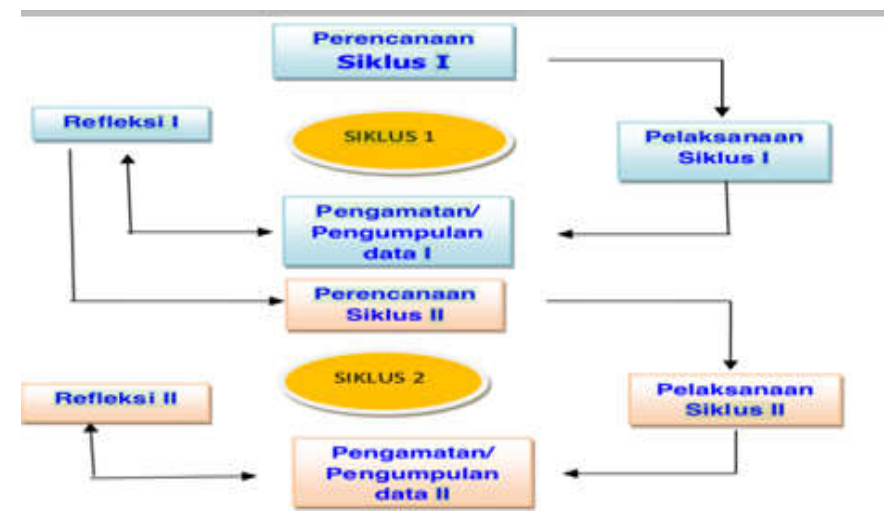

Gambar 1: $\quad$ Prosedur Siklus Penelitian Kemmis \& Taggart

Teknik pengumpulan data dalam penelitian ini adalah observasi dipergunakan untuk mengumpulkan data berupa lembar pengamatan oleh kolaborator mengenai tindakan pendidik dan perilaku sikap peserta didik dalam kelas saat mengikuti proses pembelajaran. Instrumen menggunakan lembar observasi perilaku peserta didik dan lembar observasi tindakan pendidik dilengkapi dengan catatan kronologis proses pembelajaran berupa catatan lapangan yang dibuat oleh kolaborator, instrumen ini digunakan untuk menjaring data yang berkaitan dengan proses dan situasi nyata pembelajaran di kelas, angket digunakan untuk mendapatkan respon peserta didik saat pembelajaran digunakan untuk memperoleh data aktivitas dalam proses belajar Mengajar dan tes suatu cara mengumpulkan data dengan memberikan tes kepada objek yang diteliti. Dalam penelitian ini penulis menggunakan tes hasil belajar, yaitu tes yang digunakan untuk mengukur hasil-hasil belajar yang dicapai peserta didik dalam kurun waktutertentu.

Dalam penelitian ini tes yang diberikan kepada peserta didik ada dua macam, Pre test yaitu bentuk tes yang diberikan sebelum dimulainya proses pembelajaran untuk mengetahui sampai dimana penguasaan peserta didik terhadap bahan pelajaran yang akan diajarkan.Tes yang diberikan pada setiap akhir program satuan pengajaran disebut post tes. Tujuan dari tes ini adalah untuk mengetahui sejauh mana pencapaian peserta didik terhadap bahan pengajaran setelah melalui kegiatan belajar. Untuk mengetahui peningkatan hasil belajar peserta didik maka dilaksanakan tes dengan tujuan melihat peningkatan yang diperoleh peserta didik melalui tes tersebut. 
Pada setiap kegiatan dari pelaksanaan siklus Penelitian Tindakan Kelas (PTK) dianalisis secara deskriptif dengan memakai teknik persentase untuk melihat peningkatan yang terjadi dalam setiap kegiatan pembelajaran, apakah sudah mencapai Kriteria Ketuntasan materi (KKM) yang diharapkan yakni rata-rata nilai 75 dan peserta didik yang dapat mencapai nilai KKM (Kriteria Ketuntasan Minimum) sebanyak $85 \%$ dari total jumlah peserta didik 32 orang.

\section{HASIL DAN PEMBAHASAN}

Peneliti untuk tahun ajaran 2019/2020 mendapat tugas mengajar di empat kelas yang jurusannya berbeda-beda, pada saat kegiatan belajar mengajar materi KD.3.19 tentang "Persamaan dan pertidaksamaan kuadrat", dalam kegiatan belajar mengajar penulis menggunakan metode ceramah dengan menjelaskan materi lalu memberi contoh-contoh setelah itu peserta didik mengerjakan soal evaluasi yang berbentuk essay. Saat peserta didik mengerjakan evaluasi dilakukan pengamatan (observasi) dimana peneliti mengambil data nilai awal (PH 1) merupakan hasil dari kegiatan pra siklus, ternyata peserta didik kelas XI Desain Interior dan Teknik Furnitur B sebagai subyek penelitian karena nilai rata-ratanya 63,00 pada penilaian harian $1(\mathrm{PH})$ dengan nilai terendah 32 dan nilai tertinggi 81. Peserta didik yang mencapai nilai minimal KKM hanya 19 orang dari 32 orang serta ketuntasan klasikal yang dicapai 59,38\% dibanding tiga kelas yang lain.

Tabel 1. Kondisi awal hasil belajar peserta didik berdasarkan nilai Pretest

\begin{tabular}{cllcr}
\hline No & & Kondisi awal Hasil Test & Nilai & Persentase \\
1 & Rata-rata & 63 & \\
2 & Min & 32 & \\
3 & Max & 81 & \\
4 & Kriteria Ketuntasan Minimum (KKM ) & 75 & \\
5 & Jumlah peserta didik tuntas 19 orang & & $59,38 \%$ \\
6 & Jumlah peserta didik tidak tuntas 13 orang & & $40,63 \%$ \\
\hline
\end{tabular}

Penelitian ini menggunakan metode pembelajaran MMPdiharapkan adanya peningkatan hasil belajar untuk materi persamaan dan pertidaksamaan kuadrat serta sebagai variasi dalam proses pembelajaran diharapkan peserta didik jadi tambah aktif dan semangat mengikuti kegiatan belajar mengajar. Peserta didik terlebih dahulu dibagi dalam 8 kelompok masing masing terdiri dari 4 (empat) orang mengerjakan Lembar Kerja Peserta Didik (LKPD) secara tidak langsung bekerjasama untuk kemudian tiap kelompok menunjukkan hasil pekerjaannya, ditulis di papan tulis dan dianalisa bersama sama dengan kelompok yang lain, kelompok yang lain bisa bertanya yang mungkin kurang dimengerti atau memberi masukan cara penyelesaian yang lebih praktis. Setelah peserta didik bekerja dalam kelompok kemudian pendidik membagikan Lembar Kerja Peserta Didik (LKPD) untuk dikerjakan oleh tiap peserta didik secara mandiri, selanjutnya pendidik bersama peserta didik membahas jawaban peserta didik sehingga peserta didik memahami mana jawaban yang benar dan mana yang salah. Peserta didik diberikan PR untuk menambah penguasaan materi dan peserta didik diberi tes essay untuk dijadikan dasar oleh pendidik melihat penguasaan peserta didik terhadap pelajaran matematika.

Kegiatan belajar mengajar pada siklus pertama pertemuan pertama membahas materi tentang menentukan himpunan penyelesaian persamaan kuadrat satu variabel.

Pendidikmemulai pelajaran dengan mengucap salam, berdoa dan mengecek kehadiran peserta didik sehingga diketahui peserta didik hadir semuanya. Hal itu dilakukan sebelum pembelajaran dimulai. Setelah itu, pendidik memberitahukan peserta didik tentang tahapan ]metode pembelajaran MMP dalam kegiatan pembelajaran. Selanjutnya kegiatan inti, yaitu menggambarkan serta menjelaskan tentang himpunan penyelesaian persamaan kuadrat satu variabel yaitu dengan menyuruh peserta didik melihat power point (PPT). Setelah menyaksikan power point (PPT) pendidik memberikan Lembar Kerja Peserta Didik (LKPD) 1 untuk dikerjakan secara kelompok, tiap-tiap kelompok berdiskusi untuk menyelesaikan masalah dalam LKPD 1, kemudian tiap-tiap peserta didik membuat rangkuman materi yang sudah dilakukan bersama-sama, perwakilannya mempresentasikan hasil kerja kelompoknya dan yang lainnya memberi tanggapan. Banyak peserta didik yang masih bingung dalam memberi 
jawaban soal pada LKPD 1 yang telah diberikan pendidik. Terdapat juga keluhan peserta didik karena tidak cocok dengan teman timnya. Setelah selesai mengerjakan LKPD 1 secara kelompok kemudian peserta didik diminta untuk bekerja sendiri sebagai latihan sehingga kemampuan penalaran peserta didik dapat meningkat dan sebagai sarana peserta didik untuk mengaplikasikan pemahaman yang diperoleh setelah itu peserta didik mengumpulkan hasil pekerjaannya. Pada akhir kegiatan, pendidik memberikan tugas latihan dan memberikan motivasi kepada peserta untuk semangat dalam kegiatan belajar.

Pertemuan kedua, pendidik menyampaikan salam dan doa. Selanjutnya pendidik mengecek kehadiran peserta didik memastikan seluruh peserta didik hadir pada pertemuan II. Hal tersebut dilakukan sebelum memulai pembelajaran. Materi pada pertemuan kedua ini yaitu menyelesaikan model matematika suatu masalah yang berkaitan dengan persamaan kuadrat satu variabel. Pendidik memberikan semangat pada peserta didik agar lebih proaktif dalam pembelajaran matematika, karena permasalahan pada materi ini sering dialami dalam kehidupan sehari-hari yang berkaitan dengan persamaan kuadrat satu variable.penyampaian dalam bentuk soal cerita. Dalam menyelesaiannya, terlebih dahulu membuat model matematika berdasarkan soal cerita tersebut, kemudian pendidik memberikan link pembelajaran, selanjutnya secara berkelompok peserta didik mendiskusikan soal di LKPD 2 yang telah diberikan oleh pendidik, observer berkeliling, mengamati dan memberikan bantuan kepada peserta didik yang mengalami kesulitan. Setelah mendapatkan hasil diskusi secara berkelompok, peserta didik mempresentasikan dan kelompok yang lain menyimak dan merangkum apa yang dijelaskan oleh kelompok lain. Setelah selesai mengerjakan LKPD 2 secara berkelompok kemudian peserta didik diminta mengerjakan masing-masing sebagai latihan untuk meningkatkan kemampuan penalaran peserta didik dan sebagai sarana peserta didik untuk mengaplikasikan pemahaman yang diperoleh setelah itu peserta didik mengumpulkan hasil pekerjaannya. Peserta didik bersama pendidik memberikan kesimpulan dari hasil diskusi. Tidak lupa di lain pertemuan pendidik memberikan reward bagi kelompok yang aktif berdiskusi dalam mengerjakan soal LKPD 2 , pendidik menginformasikan rencana pembelajaran untuk pertemuan berikutnya, yaitu menyuruh peserta didik di rumah untuk mempelajari materi yang telah diajarkan karena pertemuan berikutnya akan diadakan post tes individu yang digunakan sebagai tes evaluasi siklus pertama. Hal ini dilakukan pada kegiatan penutup

Pendidik berdoa dan menyampaikan salam saat menutup pelajaran. Pada pertemuan kedua pembelajaran berjalan cukup lancar. Beberapa peserta didik sudah mulai proaktif dalam berdiskusi dengan kelompoknya dan mulai aktif bertannya pada saat ada kelompok yang mempresentasikan hasil diskusi di depan kelas.

Pertemuan ketiga peserta didik diberikan soal pos test sebagai tes evaluasi siklus pertama yang dikerjakan secara individu .Pendidik membuka pertemuan dengan salam dan berdoa, mengecek kehadiran seluruh peserta didik dilakukan saat awal kegiatan. Dan memastikan seluruh peserta didik hadir pada pertemuan ketiga. Materi pada akhir siklus terdiri dari semua yang telah dibahas dalam pertemuan pertama sampai kedua. Jumlah soal tes akhir siklus I sebanyak 20 soal. Pendidik memberikan petunjuk kepada peserta didik tentang kegiatan yang akan dilakukan pada tes akhir siklus pertama.Kemudian pendidik menyampaikan soal tes akhir siklus pertama dan peserta didik mengerjakan tes akhir siklus pertama secara individu. Pendidik mengamati jalannya tes akhir siklus. Setelah peserta didik selesai mengerjakan tes akhir siklus pertama, pendidik meminta peserta didik untuk mengumpulkan lembar jawaban soal tes akhir siklus pertama.

Pada saat dilakukan postest setelah pembelajaran selesai, yaitu pada minggu ke tiga. Hasil Pengamatan Siklus pertama yang dilakukan pendidik, dari penilaian tersebut, diperoleh rerata nilai kelas belum maksimal yaitu 73. Jumlah peserta didik yang tidak tuntas atau peserta didik yang memiliki nilai di bawah 75 masih cukup banyak yaitu 8 orang atau 25\%. Jumlah peserta didik yang mencapai ketuntasan yaitu 24 orang, jadi baru mencapai 75\%. Belum maksimalnya peserta didik dal a m m e ma ha m i konsep yang dipelajarinya dalam proses pembelajaran dapat dilihat dari hasil pencapaiannya.

Permasalahan utama kekurangan dalam pencapaian indikator tersebut adalah peserta didik merasa bingung atau tidak memahami secara mendalam dari konsep-konsep yang dipelajarinya, belum dapat menghubungkan antara satu konsep dengan yang lainnya walaupun sudah dibicarakan 
dalam kelompok dan menjawab pertanyaan-pertanyaan dalam LKPD dengan tepat. $\mathrm{Hal}$ ini mungkin karena belum terbiasa belajar secara mandiri.

Siklus kedua ini akan menggunakan sistem pembelajaran yang sama. Setelah selesai berdiskusi akan menjelaskan konsep-konsep penting atau materi essensial yang harus dimengerti dan mengoptimalkan tanya jawab serta memberi perhatian yang lebih kepada yang kurang aktif

Kegiatan belajar mengajar dilanjutkan ke siklus ke dua. Tindakan pada Sebanyak 3 kali pertemuan siklus kedua dilaksanakan, tindakannya sama antara pertemuan pertama dan kedua, pada siklus pertama, hanya berbeda materi pembelajaran yaitu tentang sistem pertidaksamaan kuadrat satu variabel dan memberi perhatian khusus pada peserta didik yang kurang baik dan kurang aktif kinerjanya pada saat pemantauan diskusi kelompok-kelompok, dan pada pertemuan ke tiga, menjelang dilakukan post test pada siklus kedua ini peneliti memberi penguatan tentang hasil diskusi secara rinci pada setiap konsep yang dipelajari.

Hasil post test pada siklus kedua bahwa nilai post test peserta didik sudah sesuai indikator yang diharapkan yakni jumlah peserta didik yang sesuai ketuntasan 90,62\%, yaitu 29 orang dari total jumlah peserta didik 32 orang dengan nilai rata-rata 79.

Pada siklus kedua ini peneliti melihat bahwa pelaksanaan metode pembelajaran MMP telah dapat meningkatkan hasil belajar peserta didik, dan mencapai indikator penelitian yang ditetapkan yakni persentase peserta didik yang mencapai nilai tuntas adalah 90,62\%. Dengan demikian dapat dikatakan bahwa Metode MMP sesuai digunakan dalam pembelajaran penguasaan materi matematika, seluruh siklus yang akan dianalisis dan dibandingkan hasil penelitiannya dengan indikator yang akan dicapai. Berikut ini adalah datanya.

Tabel 2. Perbandingan hasil penelitian awal dan tiap siklus dengan indikator.

\begin{tabular}{llcc}
\hline No & \multicolumn{1}{c}{ Kondisi awal Hasil Test } & Nilai & Persentas \\
\hline 1 Rata-rata & 63 & \\
2 & Min & 32 & \\
3 & Max & 81 & \\
4 & Kriteria Ketuntasan Minimum (KKM) & 75 & \\
5 & Jumlah peserta didik tuntas 19orang & & $59,38 \%$ \\
6 & Jumlah peserta didik tidak tuntas 13orang & $40,63 \%$ \\
\hline
\end{tabular}

Jika kita lihat dari diagram hasil belajar diatas terlihat nilai rata-rata, ketuntasan, nilai maksimum dan nilai minimum semakin naik dari tahap awal sampai siklus kedua, maka dapat dikatakan bahwa metode pembelajaran MMP pada mata pelajaran matematika mampu meningkatkan penguasaan dan hasil belajar.

\section{SIMPULAN DAN SARAN}

Penelitian tindakan kelas ini berupaya mengetahui dan menjelaskan tentang capaianpeserta didik dalam aspek pengasaan konsep matematika. Hasil pra tindakan rata-rata 63 menunjukan hasil yang masih jauh dari target ketuntasan minimal yang diharapkan satuan pendidikan 75 sehingga dilakukan tindakan selanjutnya untuk melihat apakan ada peningkatan, hasil siklus pertama memberikan gambaran peningkatan penguasaan materi matematika dengan perolehan rata-rata 73 walaupun masih belum mencapai ketuntasan minimal, hasil siklus kedua ada peningkatan dengan perolehan rata-rata 79

Berdasarkan hasil tersebut bahwa pengajaran matematika materi persamaan dan pertidaksamaan kuadrat menggunakan metode MMP dapat menambah penguasaan konsep peserta didik kelas XI berada pada tingkat SMK, selain dapat meningkatkan prestasi nilai hasil belajar juga dapat mendorong peserta didik untuk menambah aktivitas pembelajaran yang positif dan menurunkan kebiasaan buruk pada saat proses pembelajaran. Oleh karena itu para pendidik diharapkan untuk memakai metode pembelajaran ini dalam kegiatan pembelajaran dan diharapkan pendidik untuk terus mengembangkan dalam menemukan strategi yang efektif guna memacu hasil belajar matematika. Disarankan kepada para pendidik agar lebih jeli dalam 
menentukan rencana tindakan yang diberikan sehingga tindakan yang diberikan tidak menimbulkan masalah baru.

Proses pembelajaran dikelas sebaiknya memakai metode, pendekatan dan strategi belajar yang lebih bervariasi sehingga memberi kemudahan pada peserta didik dalam mempelajari pengetahuan, menyediakan materi-materi menarik, membuat pembelajaran menyenangkan, peserta didik tidak mengalami kejenuhan dan memproses generasi berkualitas yang mendukung pembelajaran .

Saran untuk peserta didik agar senantiasa terdorong dalam mengikuti pembelajaran dengan kesungguhan, memiliki rasa tanggung jawab untuk menyelesaikan tugas belajar; serta memiliki kebiasaan belajar secara mandiri.

Saran berikutnya agar dapat melanjutkan penelitian ini dengan aspek yang lebih luas dan kritis. Dalam penelitian ini untuk lebih detail dalam meneliti peserta didik sehingga tidak ada kecurangan yang dilakukan oleh peserta didik dan berharap agar penelitian ini dapat memberikan manfaat dan membangun pemikiran bagi pendidik pada umumnya dan pada khususnya untuk penulis.

\section{PUSTAKA ACUAN}

Faradhila, N. S. (2013). Eksperimentasi Model Pembelajaran Missouri Mathematics Project (MMP) pada Materi Pokok Luas IPermukaan Serta Volume Prisma dan Limas Ditinjau dari Kemampuan Spasial Peserta didik Kelas VIII Semester Genap SMP Negeri 2 Kartasura Tahun Ajaran 2011/2012. Jurnal Pendidikan Matematika So/usi, 1(1), pp. 67-74.

Hamdani. (2017). Strategi Belajar Mengajar. Pustaka Setia.

Mukhtar. (2013). Pengembangan bahan ajar matematika berbasis masalah untuk memfasilitasi pencapaian kemampuan penalaran dan pemahaman konsep peserta didik. Maka/ah seminar FPMIPA Universitas Lampung.

R.Rukmini. (2018). Penerapan Metode Inquiry Based Learning Dalam Upaya Peningkatan Hasil Belajar Matematika Yang Memuat Himpunan Penyelesaian Persamaan Dan Pertidaksamaan Linear Dan Kuadrat Pada Peserta didik Kelas X Semester 1SMK !Negeri 2 Boyolangu Tulungagung Tahun Pelajaran 201. Pendidik. Dasar dan Menengah, vol. 4, no. 1,

Rahmawati, W. (2017). PERBANDINGAN !MODEL PEMBELAJARAN MISSOURI MATHEMAT ICS.

Ritonga.Nurmasitoh. (2019). Pengaruh Model Pembelajaran Open Ended Dan Model Pembelajaran Missouri Mathematics Project Terhadap Kemampuan Berpikir Kritis Dan Kemampuan Pemecahan Masalah Di Kelas XI SMA.

Sartina, A.T. (2018). MODIFIKASI MODEL PEMBELAJARAN MISSOUR I MATHEMATICS PROJECT. Jurnal AKSARA PUBLIC Volume 2 Nomor 4 Edisi Desember 2018, 23-38.

Setiawan, R. A. 17). PENGARUH MODEL PEMBELAJARAN MISSOUR I MATHEMATICS PROJECT (MMP) UNTUK MENINGKATKAN MOTIVAS I DAN PRESTAS I BELAJAR S ISWA DALAM PEMBELAJARAN MATEMATIKA KELAS VII SMP N 1 SEYEGAN.

SriAdi.Widodo.(2011). EFEKT IFITAS MODEL PEMBELAJARAN TEAM ACCELERATED INSTRUCT ION PADA PESERTA DIDIK KELAS X SMK TUNAS HARAPAN TAHUN PELAJARAN 2008- 2009. Pemantapan Keprofesionalan Peneliti, Pendidik dan Praktisi MIPA Untuk Mendukung Pembangunan Karakter Bangsa/SSN 978-979-99314-5-0.

Sugiarto, F. E. Keefektifan Impementasi Model pembelajaran Missouri Mathematics Project (MMP) materi pokok persamaan dan pertidaksamaan kuadrat. Skripsi FMIPA UNNES, 55.

Suhita.R. (2013). Analisis kesalahan dalam menyelesaikan soal cerita dalam matematika.Pendidikan Matematika, 1.

Suwito. (2013). Eksperimentasi Pembelajaran Matematika dengan Model Pembelajaran Kooperatif melalui MMP (Missouri Mathematics Project) dan GI (Group Investigation) Ditinjau dari Kecerdasan Emosional dan Gaya Belajar Peserta didik pada Peserta didik SMIP di Kota Blitar. KadikmA, 4(2), pp. 1-12. 